\title{
The problem of moral choice in political ethics
}

\author{
E. V. Derzhivitskii, I. Yu. Larionov
}

St. Petersburg State University,

7-9, Universitetskaya nab., St. Petersburg, 199034, Russian Federation

For citation: Derzhivitskii E. V., Larionov I. Yu. The problem of moral choice in political ethics. Vestnik of Saint Petersburg University. Philosophy and Conflict Studies, 2019, vol. 35, issue 3, pp. 406-416. https://doi.org/10.21638/spbu17.2019.302

In this paper, we identify and describe the particular characteristics of moral choice in political ethics. For that purpose, the main features of political ethics as applied ethics, as well as its difference from other areas of applied ethics, are revealed. We describe the method and the limits of interpretation of political ethics as professional ethics. We come to the conclusion that in some cases of political choice we cannot appeal to norms and principles of public morality. The reasons are the ineradicable properties and goals of political activity-that is, its significant impact on the welfare and lives of citizens of the state, a high degree of risk and uncertainty, and the continuous presence of open ethical questions. On that ground, we argue that in the case of moral choice political ethics should analyze each situation separately, since any attempt to create universal prescriptions and recommendations would inevitably fail as inappropriate. Hereafter, we propose the typology of ethical conflicts typical for political practice. The first type is the moral conflict caused by the necessity of political compromise that presupposes breaking previous promises. The second type is proper moral dilemmas that include the choice between life and death of other people. The third type presents the choice between some historically significant goals and the personal political career of a politician. In the discussion, we will provide real-life examples for each type of political moral conflict. The main research methods of the paper are categorical analysis of ethical concepts, comparative analysis, cultural-historical method, analysis of moral dilemmas, event analysis, politicalpsychological method, method of political-cultural comparative studies, and content analysis. Keywords: political ethics, moral conflict, moral choice in politics, compromise, lies in politics, moral motivation of politicians, the responsibility of politicians, political suicide.

In this paper, we investigate the problem of ethical choice of politician both as a person and as an actor of social relationships. First, we will address the subject of relation between politics and morality. On this ground, we specify the concept of political ethics as well as the particular characteristics of ethical decision in politics. In the second part of the paper we propose the typology of ethical conflicts typical for the political practice.

At the beginning of our discussion on political ethics, we would like to conceptualize it as a form of applied ethics.

The generalized definition of applied ethics could run as follows: "Applied ethics is the theory and practice of applying ethical norms and values to the variety of problematic situations both in public, professional and private life." The applied ethics is embodied in

* With the support of Russian Foundation for Basic Research (RFBR), project №19-011-00234 “Moral normality in professional ethical codes in the conditions of formation of a digital society".

(c) Санкт-Петербургский государственный университет, 2019 
several disciplines distinct from one another such as bioethics, business ethics, environmental ethics, legal ethics, etc. Therefore, political ethics could be regarded as an example of the applied ethics as well.

Unfortunately, the subject matter and the correlation between the theoretical and practical components of each above mentioned type of applied ethics still constitute a conceptual problem. In case of theoretical study of political ethics, it is the characteristics of political life that need to be taken into consideration.

Being a part of human life, politics has a series of typical characteristics that we could observe anytime and anywhere in the world. At the same time, politics frequently gives rise to unique problems and cases, which do not fall within the scope of standard social norms and values, including moral norms and values. Thus, in order to clarify the concept of political ethics we need to consider the special status of political action and political choice.

This is a common point of view, both among people who engage in political activity and those who have almost no interest in politics, that politics is a kind of dirty business, and even a genuine service for the sake of people and their welfare inevitably goes hand in hand with violation of some moral norms.

Here the important comment is to be made that such activities as corruption as well as abuse of political power, or intentional deception, betrayal, etc., carried out to one's personal advantage or for promoting interests of a political party, are not the subject of this paper. That kind of deeds gives us almost no resources for the ethical analysis and pertains to the field of legal science, physiology or political science.

We regard politician as a public person, who acts not only upon self-interest but also in terms of political rationality and the common good (bonum commune).

It is much more important for the political ethics to explain the dissonance between political choice, political action and the violation of moral norms, which the political choice may occasionally require.

The established point of view of the majority of contemporary researchers that we endorse here is that we need to make a clear distinction between the normative ethics (especially the ethics of universal rules and values) and the political ethics as a part of applied ethics.

It was Cicero who drew the important distinction between justice and political expediency: "we, truly the most just of human beings, not permit the Transalpine nations to grow olive and vine, so that our olive groves and vineyards will be worth more! When we do this, we are said to do so prudently; but we are not said to do so justly" (De re publica, III: IX,16: Fott (2014) [1].

As the German political philosopher Bernhard Sutor states, politics always has a moral side and is to comply with the moral values, but at the same time we cannot discuss and evaluate politics on the basis of moral considerations only [2, p.31].

In his influential article "Political Action: The Problem of Dirty Hands" Michael Walzer promoted the term "the dirty hands" and discussed the crucial dilemma in politics that is the alleged possibility to perform unjust acts for the sake of the common good. Walzer claimed that politician could be regarded to be honest if she or he inflicts harm voluntarily and consciously but at the same time is sensible of all possible consequences and even feels guilty. Walzer called for the close attention to the internal side of "moral" choice that a politician makes [3]. 
Bernard Williams in his essay "Politics and moral character" also makes a clear distinction between the ordinary morals and political ethics [4, p. 69-70].

The similar opinion was expressed by Russian scholar Boris Kapustin who warns us against a simple incorporation of morals into politics. For Kapustin, the nature of politics is the conflict that is always related to some form of violence. It is not uncommon that the violence in politics affects the life and death of citizens, so we cannot build the political relationships in accordance with the golden rule because that would paradoxically lead not only to political defeat but also to betraying your followers and doing favor to evil $[5$, p. 4].

Thus, morality and political ethics are not the same. Political action cannot be discussed in terms of common moral consciousness or public morality. One shouldn't just claim that all politicians have their hands dirty. Political ethics should take into account the specifics of the political life that is the continuous presence of conflicts and the necessity for politicians to make tough choices.

The political ethics is a part of applied ethics that analyzes the specifics of the manifestation of morality in political life and determines the limits of what is permissible in political activity.

Quite often the applied ethics is interpreted as a part or a subdivision of the professional ethics. To some extent, it is true because the applied ethics came into being in various professional areas and was aimed at solving the moral problems of some particular professional practice.

Each period of the history as well as each society form the conditions to define the essence, the value, the goals and objectives for a particular professional practice. Those conditions serve as the basis of the system of norms and values for the professional community and the formal and informal framework for the professional choices. In other words, it is the society that determines the way a politician should act. The goals significant for a given society form the criteria for the principles and norms of each profession.

This set of the principles and norms could make a firm and unambiguous moral foundation for the professions related to politics. However, we need to take into account those aspects of the activities of politicians that require a specific approach to the practical guidelines and rules of ethical decision making for the areas of professional activity we are considering. It is the crucial distinction that produces a lot of problems, namely the distinction between the values associated with the interests of society, the principles that are set in regulatory documents, the norms that are manifest themselves in human behavior and, finally, real practice. This discrepancy makes it difficult to study the political ethics as an institutionalized professional ethics.

Another important aspect is the existence of so-called open problems, for example, the justification the practice of civil disobedience, the double effect problem, the discussion on invasion of privacy etc. The controversies like those cause uncertainty in moral evaluation. The debatable, unresolved problems are the real challenge for a politician who tries to follow some professional ethical principles but is forced to act in a real time limit with the burden of ethical choice and responsibility imposed solely on her or him.

Now, it is crucial to take into consideration that politic action is a professional activity that deals directly with people's life and destiny. Therefore, it is connected with the burden of deciding on the rights, property and future life of people, that is of making decisions that are irreparable. 
Perhaps when politicians are accused of immorality, most commonly they are accused of lying. Even whose people who allow lying in their private life deem it impermissible for politicians to lie whatsoever, or to lie for their electorate at least.

Here, we should draw a distinction between two purposes of lying. The one is the intended lie for acquiring a personal advantage or some preferences for their own party or benefactors. Another form is the deliberate deceit under the necessity of choice between the bigger and lesser deception or between the lying and the honesty that could bring about even more harm. The second type of lie relates to the scope of political ethics.

It is clear that it is hard to establish a clear boundary between the motives why politicians lie. However, it seems that we could try to distinguish between the "black" and "white" lies in politics, which will allow to discuss the issue of the "white" lie not only for blaming it.

After the elections to the German Bundestag in September 2017, Angela Merkel proceeded to form a government but she was faced with two serious troubles. The first problem was the worst result of the CDU/CSU coalition, that she is leader of, compared to previous elections. The second problem was the remarkable increase in the popularity of competing political parties. In order to form a government, Merkel needed to make serious concessions and enter into an alliance with her former opponents. But this meant giving up part of her election promises. The ideological differences did not allow making an alliance with the Social Democratic Party of Germany (SPD) previously. But Merkel was forced to give that party several ministerial posts. What made the matter worse was that she surrendered to blackmail by The Greens and agreed to start implementing their project to ban completely the use of vehicles with an internal combustion engine from 2030.

According to experts, fulfilling this demand of environmental protection will lead to a serious transformation of the automobile industry in Germany. This would entail job cuts for those to whom Merkel had promised economic development after her victory.

Despite these difficulties, Merkel chose to form the government and provoked a barrage of criticism. The head of the SPD Martin Schulz was subjected to similar criticism in treachery and collusion with an ideological opponent.

In the eyes of their voters, the agreement of Merkel and Schulz to form a government seemed to be a violation of their promises and the proof of their mendacity. But that was not the case for the political reality. Politics is one of the general tools for resolving conflicts in society. The state as the material embodiment of politics is one of the most effective institutions for maintaining social peace and the power of law.

The specific character of the political way of resolving conflicts is that any decision will be effective if it meets the opinion of the majority of citizens. However, this requires the unique personal qualities, the special expertise and even a great deal of craft, since contemporary society is extremely fragmented.

In his book "Political Representation," F. Ankersmit dedicated one of the final chapters to discussing the ways of acquiring the unity of society by means of political compromise ("Compromise and Political Creativity" [6, p. 193-214]. As Ankersmit puts it, there are two ways to achieve the unity of society in contemporary politics, i.e. consensus and compromise. Compromise requires the recognition of opponents. We should recognize our opponents despite the fact that they are committed to opposing political principles that could be unacceptable to us. Secondly, a compromise is possible only if 
there is a mutual desire to fulfill the obligations under the agreement, no matter how unpleasant it may be. Thus, the compromise promotes such virtues as tolerance, mutual respect and respect of the moral autonomy, trust, which guarantee the successful activity in pluralistic society. On the contrary, we cannot achieve that goal by means of consensus.

Contemporary politics is representative politics. This means that politics represents almost all political forces as the interests of almost all strata of society. The parliamentary system of government in continental European countries is characterized by political competition and the absence of a solid monopoly of power (that is the absence of a single representative). This diversity is projected on the structure of legislative body, and consequently on the structure of the executive power. This political system is a result of the long evolution. Currently, politicians have no opportunity to engage in politics simply as a kind of art of government at present, because of the class, religious, ideological, national, linguistic, regional, and gender conflicts. Therefore, compromise became a method of preventing social conflicts, especially in the most acute stages.

Usually, conflicts have a complex structure, since there are a lot parties involved. In the conditions like these there are no ready answers. According to Ankersmit, those citizens deserve moral respect, who are ready to recognize the alternative position and put their point of view to the test, that is give way to a compromise.

No matter how pragmatic, the compromise is the reason why politicians are accused of lying. First, when politicians make mutual concessions they are usually blamed for betrayal the values they promised for their electorate to uphold. Secondly, politicians accept a compromise on behalf of their voters, but without their personal consent. Thus, politicians are accused of appropriating the right to interpret arbitrary the values of voters for the sake of self-interest.

Could we find an ethical meaning of this kind of mutual concessions in politics? The first argument is that society will disintegrate if it has not a minimum unity in values value. The second reason to place compromise in an ethical layer of political activity is that politicians, unlike professionals in other areas of social life, can not refuse to make a choice at all. Politicians are obliged to bring the bargain to the end and make a deal, no matter how bad it may be. At the same time it is not a personal choice that politician makes and she or he is responsible for the interests of voters. If political person escapes this kind of choice, it would be a political suicide that would result in voters' disappointment. Moreover, the substantial part of the live of the politician would lose its meaning.

To sum up, a political compromise is ethically justified way of action, although this proposition contradicts the common moral point of view. Compromise is connected with social conflict and the necessity for ethical choice.

The ethical conflict as it is described above could be presented as a choice between the bigger or lesser evil. But we have seen that it has a lot of complex characteristics so we cannot interpret it simply as a form of that kind of choice. For this reason, we need to distinguish the second type of ethical conflict in politics.

It is the situation then the politician has to choose one group's of citizens life or health and welfare over another's. Fortunately, this type of choice is rare enough and could be perceived as a real burden for a political person. In any circumstance, the necessity of this choice is a part of political activity any politician could be faced with. The cases of similar choices could occur during warfare and in medical ethics. 
It's worth noting that the second type of ethical conflict in politics is determined with the general welfare of the state and its citizens regardless of their political attitudes and usually is not the representation of current political actors and political struggle.

Let us take as an example the decision that is attributed to Winston Churchill who, being the UK Prime Minister, had the final word in a case of V-1 flying bomb attacks of London. During the 1944 Nazi forces used this new type of weapon against the civilians resulted in thousand of deaths. At the same time, due to the incompleteness of the V-1 targeting system they didn't reach the city center and it was the southern part of London that turned to be the target of the bombing. The Nazi intelligence services were in want of the exact data so UK secret service used the double agents to provide the false information about the results of the air attacks. As estimated, that mission saved the heavily populated central areas of London. During the Second World War, "Churchill... faced excruciating moral dilemmas on an almost daily basis" [7, p. 3-7].

From a theoretical point of view, this form of choice corresponds with the famous thought experiment referred as the trolley problem. The trolley problem remains the central point in the discussions about moral dilemmas for now.

The classic version of the trolley case was provided by J.J. Thomson on basis of paper by Phillipa Foot [8]. The unpiloted and uncontrollable trolley (or a train, a car etc.) goes by a track and will inevitably hit and kill five people. If somebody turns a switch and diverts the trolley to a side track it will kill another person but only one. In both cases those people cannot escape the trolley. At the same time, those people are not responsible for being on the rails. Imagine you are able to turn the switch, diverting the trolley to the side and it is the only possible way to save five people.

The cases like this have two important attributes. It entails an active choice to inflict harm to some person or group of people. Any kind of inaction would be a choice as well, but the worst kind of choice as we stated above.

At the same time, the person who makes a choice doesn't inflict an immediate harm to her or himself. However, she or he does not act in some own interests.

These two conditions of this crucial choice are typical for the status of political person.

Here we touch on the issue of the existential components of the political activity that is the occasional necessity to face the deep ethical conflicts of this kind. The essential point to remember is that, in most cases, a politician couldn't be held accountable for being in this type of the choice situation. In the majority of cases, those situations are the unhappy combination of circumstances or they originate from unjust social institutes and political order.

In real political life this kind of choice could not be realized as a perfect autonomous decision. We should also consider the major conditions as a general welfare, the political perspective of a choice as well as various situational factors.

On the other hand, the phenomenological aspect of this type of ethical conflict is also important. Here we can go deeper in the individual psychological properties of the choice because it gives us the opportunity to unravel some specific characteristics of political ethics.

This type of political choice could be regarded as a moral dilemma because each alternative is morally approved in some respect at the same time. It is a disaster to leave a thousand people for dead but it is the salvation of thousand of thousands that could justify that sacrifice. 
For the political ethics however the morally approved alternatives as well as a possibility of moral justification are not really the point. The crucial component is the uncertainty that quite often comes with a certain degree of risk. Needless to say that this choice supposes a responsibility as well that could be placed on politician post factum. Following the final paragraphs of "Politics as a Vocation" by Max Weber, M. Walzer states that the politician has to take the burden of choice no matter how hard and painful it would be and should "be honored for making the right decision when it was a hard decision to make" [3, p. 168]. For Walzer, it is essential for a politician to be under deep moral stress while being engaged to that type of ethical conflict.

The classical philosophical analysis of moral dilemmas gives us understanding of the specific character of such form of ethical conflict and even the exceptional nature of political ethics. E J.Lemmon, who provided the first systematical discussion of moral dilemmas in contemporary ethics, considered it possible to single out the extreme kind of dilemma when person has no distinctive moral theory to comprehend and solve it. This ethical conflict challenges our ordinary moral outlook and even makes us to do hard work of moral rethinking. E. J.Lemmon suggested the case of negotiations of A. N. Chamberlain with Hitler as a real instance of this kind of moral challenge. For Lemmon, Prime Minister Chamberlain failed to asses all moral aspects of this conflict in a proper way [9, p. 156-157].

An example of the third type of moral conflict in politics is the motivation of the last white President of South Africa, Frederik Willem de Klerk, who dismantled the apartheid regime in this country.

The consequences of this choice for de Klerk himself are important here. On the one hand, there was the objective need for that decision of de Klerk because of the third wave of democratization that had changed the attitude towards the apartheid regime in international politics and increased the international pressure on him. De Klerk acknowledged that he was impressed by the fall of the Berlin Wall. At the same time, de Klerk was an experienced politician and it is obvious that he realized the consequences of his personal choice both for himself and for the white minority in South Africa. In 1993, the transitional government proclaimed that its goal is the national reconciliation and building a harmonious society. Unfortunately that goal was not achieved. Three years after that, de Klerk resigned from the office of Second Vice-President, that was a symbolic position designed to give the appearance of a compromise reached. One more year later, he completely quit political life.

But the consequences for the Afrikaners in South Africa were much more dramatic. Many people were forced to leave the country. Those who remained experienced violence and all those events were associated with the decision de Klerk had made. So, for the white citizens of the country he became a traitor.

In this case, it is important to focus on the fact that de Klerk was obviously aware of the consequences that his policies would lead to.

There was almost no country on the African continent that maintained the interracial peace and harmony after gaining independence as a result of decolonization, even if the principles of reconciliation and peaceful transit had been previously declared. Sooner or later, the white minorities began to undergo economic and social discrimination. In his autobiography, de Klerk provides the examples of how the leaders of the African National Congress, that was the main opposition force, refused to discuss the special policies for 
facilitating the shifting away from racial segregation. Moreover, since the beginning of the 60 s the ANC had its own military organization.

In that situation, de Klerk had two options behind him. The first was to keep the status quo and establish an authoritarian and repressive dictatorship in South Africa that would result in economic, political and cultural degradation of the country. The second option was to offer the ANC a compromise that entailed the inevitable risk of eliminating Afrikaners from political life and even from the legal and social sphere in the future.

As a moral person, de Klerk could have a kind of choice and speculate what would be the better moral solution (i.e. to avoid the choice and retire from politics). But it was impossible for de Klerk as a political person to engage himself in the moral decision making process. Politician "may operate in a very docile and citizenly environment. He may be lucky. He may even have, as a few seem to have, a virtue or moral cunning which drives such situations away. But it is a predictable and probable hazard of public life that there will be these situations in which something morally disagreeable is clearly required. To refuse on moral grounds ever to do anything of that sort is more than likely to mean that one cannot seriously pursue even the moral ends of politics" [4, p.60].

But in terms of the possible consequences, de Klerk's decision seemed rather questionable. He saw the example of the dramatic results of the modernization in the USSR that affected Mikhail Gorbachev who was the initiator of those changes. At the same time, de Klerk also took into account the ineffective attempts of the Serbs as a politically dominant ethnic group in Yugoslavia to keep their position using force in order to prevent other nations from managing their own future independently. It seemed obvious, that the policy of a compromise between the ruling elite and the opposition, which led to the dismantling of socialism in Eastern Europe, was the most preferable option. From the point of view of real politics, it was a case of the strictly rational choice de Klerk was in.

However, de Klerk could also have a religious motive.

The South Africa Afrikaners are known to be very pious people. De Klerk also belonged to the Dutch Reformed Church that has the canons dated back to the 16th century Calvinism. De Klerk should have perceived the task before him not as a responsible personal decision but as a divine command as well. In any case, he could not evade this mission, since as a person being chosen to accomplish the will of God he has no space for a moral choice or personal doubts.

The argument for this interpretation of de Klerk's motives to be valid could be found in the text of his President's Oath in 1990: "For me, it was far more than just a formality. I experienced it as though I was indeed standing before God and quietly promised that I would try to carry out the responsibility that He had entrusted to me with the biblical principles of justice, peace and charity as my guidelines". As we can see, the moral arguments were less important to de Klerk: "My inaugural speech was well received - not only by those present, but also by the media. Now I was state president in my own right: no longer acting as a result of a crisis in the National Party, but duly elected in terms of the constitution of that time. I was deeply aware of the responsibility that went with the position. I had no illusions about the enormity of the task that awaited me and my team, but I was full of the confidence that accompanies the conviction that one is on the right road" $[10$, p. 151].

From the utilitarianist point of view or the pragmatic approach, de Klerk's decision was equivalent to deliberate political suicide. However, in the perspective of the religious 
version of political ethics he adhered to, he achieved a victory, although he understood clearly that he would become a traitor in the eyes of the white Afrikaners. Here is how he motivated his decision to withdraw from political activity: "I had to consider my responsibility to my church, party and society. There were tremendous - and mostly well intended - pressures on me to turn back. Friends in my church appealed to me to take a moral stand akin to the political stand that I had taken on 2 February 1990. Powerful religious, political, moral and personal arguments were advanced - all of them related to my religion, place in history and the fact that I had become an important role model in more than just politic" [10, p.367]. Here, we have an example of firm conviction that faith and historical mission requires certain personal decision that will be recognized by the pious compatriots sooner or later. Thereafter, de Klerk made no attempt to excuse himself in his public speeches or in his autobiography.

The politicians are inclined to impose a certain mission on themselves or at the very least to perceive themselves as leaders, whose contribution to politics would be highly appreciated in the future. However, we have few examples of the fact that any successful political person (let us emphasize this point) would voluntarily retire to private life after achieving those great goals. And this was exactly what Frederik de Klerk did.

In our interpretation, the example of the political choice of de Klerk shows that political ethics may include the effects of individual morality. For political person, the belief in the moral correctness of her or his decision, even if that decision is not perceived as morally justified by the majority of citizens, is a necessary component of both the political activity itself and the solution of ethical conflicts in the political sphere. This belief in the moral correctness is one of the strong arguments in favor of political advisability of a political decision.

It is important that, unlike the professional choice in other significant expert communities, decision of politician involves the most serious consequences for the whole state and society, which is a specific feature of this type of decision. Therefore, we could allow the use of individual morality by the politicians only if they perceive their "mission" in the distinct limits of human and personal abilities.

\section{Conclusion}

In spite of being a type of applied ethics, political ethics cannot be expressed in the form of professional codes, clear instructions or even general recommendations. We could make the classification of the cases that are close in content and the optimal way for being resolve, but this typology would not allow us to construct the general model or develop the set of ethical norms and rules in political ethics. Every case needs to be considered ad hoc.

The cases when politicians violate their promises do not prove that they are immoral people since it constitutes a part of their professional skills and expert competence. However, this proposition can not be used as the justification of conscious lying, deception, betrayal etc.

The common moral norms couldn't be used in applied ethics including the political ethics. Following the norms of common moral consciousness in the case of a complex ethical conflict in politics would sometimes produce more harm to society than the pragmatic choice of lesser evil. Every subjective moral preference should give way to objective goals and tasks that comply with general welfare of the state and its citizens. 
What is more, the general normative consent (or consensus) about moral values or fundamental principles and moral justification of moral choice could inflict harm in political ethics. The specifics of the political sphere of society and the existing relations between the main actors in it prove that it is compromise that would be efficient, desirable and ethically justified way of conflict solving. Compromise is a form of consent when parties respect each other's interests and are willing to give up some part of their demands in exchange for a similar refusal from the side of other party.

The case of political choice is characterized with the lack of complete and reliable information, as well as with the difficulty to predict accurately the reaction of those who would be affected by this choice and the intervention of unforeseen circumstances. Since it is impossible to foresee all the consequences of a political decision, when evaluating a political choice we need to take into account the conditions under which this choice of a political person was made and a main motive of that person. As for the motive of a political person, it could be considered as ethically justified when this person imposes on her or his self consciously and voluntary some form of responsibility for the choice in a hard situation of ethical conflict.

\section{References}

1. Fott, D. (2014), Marcus Tullius Cicero, "On the Republic" and "On the Laws", trans. by Fott, D., Cornell University Press, Ithaca, $377 \mathrm{p}$.

2. Sutor, B. (2001), The little political ethics, in Political and economic ethics, FAIR-Press Publ., Moscow, pp. 27-174. (In Russian)

3. Walzer, M. (1973), Political Action: The Problem of Dirty Hands, Philosophy and Public Affairs, vol. 2, no. 2 , pp. $160-180$.

4. Williams, B. (1981), Politics and moral character, in Williams, B. Moral Luck: Philosophical Papers 1973-1980, Cambridge University Press, pp. 54-70.

5. Kapustin, B. G. (2004), The moral politics and the political morality. Preface, in Kapustin, B. G. (ed.), Moral' v politike. Khrestomatiia, MSU Publ., Moscow, pp. 3-38. (In Russian)

6. Ankersmit, F. R. (2002), Political Representation, Stanford University Press, Stanford, 266 p.

7. Edmonds, D. (2014), Would You Kill the Fat Man?: The Trolley Problem and What Your Answer Tells Us about Right and Wrong, Princeton University Press, Princeton, $240 \mathrm{p}$.

8. Thomson, J. J. (1985), The Trolley Problem, The Yale Law Journal, vol. 94, no. 6, pp. 1395-1415.

9. Lemmon, E. J. (1962), Moral Dilemmas, The Philosophical Review, vol. 71, no. 2, pp. 139-158.

10. De Klerk, F. W. (1999), The Last Trek - A New Beginning. The Autobiography, St. Martin's Press, New York, $412 \mathrm{p}$.

Received: February 13, 2019

Accepted: June 13, 2019

Author's information:

Evgenii V.Derzhivitskii - PhD in Philosophy, Associate professor; e.derzhivickij@spbu.ru Igor Yu. Larionov - PhD in Philosophy, Associate professor; i.larionov@spbu.ru 


\title{
Проблема морального выбора в политической этике
}

\author{
Е. В. Держивичкий, И. Ю. Ларионов
}

Санкт-Петербургский государственный университет,

Российская Федерация, 199034, Санкт-Петербург, Университетская наб., 7-9

Для цитирования: Derzhivitskii E. V., Larionov I. Yu. The problem of moral choice in political ethics // Вестник Санкт-Петербургского университета. Философия и конфликтология. 2019. Т. 35. Вып. 3. С. 406-416. https://doi.org/10.21638/spbu17.2019.302

В статье предпринята попытка определить и описать специфику морального выбора в политической этике. Для этой цели выявлены характерные черты политической этики как прикладной этики, ее отличие от других направлений прикладной этики. Далее показано, каким образом и с какими ограничениями политическая этика может рассматриваться как профессиональная этика. Определяется, что дилеммы, встающие перед политиками, не могут разрешаться в нормах и принципах общественной морали. Обосновывается положение о том, что неустранимые свойства и цели политической деятельности, ее существенное воздействие на благосостояние и жизнь граждан государства, высокая степень риска и неопределенности, а также наличие открытых этических проблем не позволяют прибегать в политике напрямую к обыденной нравственности или универсальным этическим теориям. В силу этого выдвигается положение о том, что в ситуации морального выбора политическая этика ориентирует скорее на разрешение каждой ситуации отдельно, поскольку попытка создания универсальных предписаний и рекомендаций неизбежно окажется бесплодной. В статье предлагается типология конфликтных ситуаций, специфических для политической этики. Первый тип - моральный конфликт, вызванный необходимостью политического компромисса, который требует нарушения политиком данных ранее обещаний. Второй тип - собственно моральные дилеммы, предполагающие выбор жизни или смерти других людей. Третий тип представляет собой выбор между политической карьерой самого политика и реализацией исторически значимых целей и задач. Характеристика каждого из данных типов этического конфликта сопровождается анализом примеров из политической практики. Основные исследовательские методы статьи: этико-категориальный анализ, сравнительный анализ, культурно-исторический метод, анализ моральных дилемм, ивент-анализ, политико-психологический метод, метод политикокультурной компаративистики, контент-анализ.

Ключевые слова: политическая этика, моральный конфликт, моральный выбор в политике, компромисс, ложь в политике, моральная мотивация политиков, ответственность политиков, политическое самоубийство.

Статья поступила в редакцию 13 февраля 2019 г.; рекомендована в печать 13 июня 2019 г.

Контактная информация:

Держивицкий Евгений Викторович - канд. филос. наук, доц.; e.derzhivickij@spbu.ru Ларионов Игорь Юрьевич — канд. филос. наук, доц.; i.larionov@spbu.ru

* При финансовой поддержке гранта Российского фонда фундаментальных исследований (РФФИ) №19-011-00234 «Моральная нормативность в профессиональных этических кодексах в условиях формирования цифрового общества». 